\title{
Separation of $\mathrm{Pb}$ (II) Ion with Tetraacetic Acid Derivative of Calix[4]arene by Using Droplet-based Microreactor System
}

\author{
Yehezkiel Steven Kurniawan ${ }^{1}$, Mizuki Ryu', Ramachandra Rao Sathuluri ${ }^{1}$, Wataru Iwasaki ${ }^{2}$, Shintaro \\ Morisada $^{1}$, Hidetaka Kawakita ${ }^{1}$, Keisuke Ohto ${ }^{1,}$, Masatoshi Maeki ${ }^{3}$, Masaya Miyazaki ${ }^{2}$, and Jumina ${ }^{4}$ \\ ${ }^{1}$ Department of Chemistry and Applied Chemistry, Faculty of Science and Engineering, \\ Saga University, 1-Honjo, Saga 840-8502, Japan
}

${ }^{2}$ Advanced Manufacturing Research Institute, National Institute of Advanced Industrial Science and Technology, 807-1 Shuku, Tosu, Saga 841-0052, Japan

${ }^{3}$ Division of Applied Chemistry, Faculty of Engineering, Hokkaido University, Kita, Sapporo 060-0808, Japan

${ }^{4}$ Department of Chemistry, Faculty of Mathematics and Natural Sciences, Universitas Gadjah Mada, Sekip Utara, Yogyakarta 55281, Indonesia

* Corresponding author:

tel: +81-952-28-8669

email:ohtok@cc.saga-u.ac.jp

Received: March 3, 2018

Accepted: May 15, 2018

DOI: $10.22146 /$ ijc.34387

\begin{abstract}
In this study, the microreactor system was investigated and compared with the batch-wise system as rapid and effective extractive $\mathrm{Pb}(\mathrm{II})$ separation over $\mathrm{Fe}(\mathrm{III})$, $\mathrm{Cu}(\mathrm{II})$ and $\mathrm{Zn}$ (II) with tetraacetic acid calix [4]arene. By using a microreactor system, the $\mathrm{Pb}(\mathrm{II})$ extraction percentages reached the maximum of 73,89 and $100 \%$ in 8 sec residence time at equilibrium $\mathrm{pH}$ of 2.00, 2.25 and 2.50, respectively. The stripping percentage was $92 \%$ at $8 \mathrm{sec}$ residence time by using a microreactor system with $2.0 \mathrm{M} \mathrm{HNO}_{3}$ as a stripping reagent. Complete separation of $\mathrm{Pb}(\mathrm{II})$ over $\mathrm{Fe}(\mathrm{III}), \mathrm{Cu}(\mathrm{II})$ and $\mathrm{Zn}$ (II) ions with the tetraacetic acid calix[4]arene in a competitive metal system was achieved at pH 2.00. However, the batch system required $24 \mathrm{~h}$ to reach the equilibrium for both extraction and stripping processes. The results suggested that the microreactor system enhanced the $\mathrm{Pb}(\mathrm{II})$ extraction and stripping rate up to $10^{4}$ times faster than the batch-wise system.
\end{abstract}

Keywords: microreactor; $\mathrm{Pb}(\mathrm{II})$ extraction; separation; calix[4]arene

\section{- INTRODUCTION}

Efforts concerning environmental research to reduce and prevent environmental pollution, such as green chemistry, renewable resource, efficient operation process and wastewater treatment, are increasing rapidly [1-6]. Amongst, wastewater treatment attracts worldwide attention for its serious effects on the ecosystem, especially in the developing countries. Once the toxic chemicals released into the environment, which reflects on human health damage. One of the main parameters of water pollution is the presence of heavy metals concentration, such as lead $(\mathrm{Pb}(\mathrm{II}))$, cadmium $(\mathrm{Cd}(\mathrm{II}))$, mercury $(\mathrm{Hg}(\mathrm{II}))$ and so on [7]. $\mathrm{Pb}(\mathrm{II})$ ion is commonly found in the environment from the mining and industrial activities. Even at the low concentration, $\mathrm{Pb}(\mathrm{II})$ pollution could damage the central nervous system and cause mortality [8]. Therefore, $\mathrm{Pb}(\mathrm{II})$ removal process has gained the highest interest over the past several years [913].

Solvent extraction is one of the widely applied separation methods, in which the extraction efficiency mainly determined by the extraction reagent properties. Several commercial extraction reagents evaluated for efficient $\mathrm{Pb}(\mathrm{II})$ separation, however, their separation ability and efficiency not good enough, especially to apply in wastewater treatment, the $\mathrm{Pb}$ (II) concentration is in traces while iron ( $\mathrm{Fe}(\mathrm{III}))$, copper $(\mathrm{Cu}(\mathrm{II}))$ and zinc $(\mathrm{Zn}(\mathrm{II}))$ concentrations are very high. Calix[4] arene is one of the well-known host compounds due to its discriminatory ability. The size fitting effect and softhard nature of its coordination site are the main factors that contribute to calix[4] arene discrimination ability 
[14]. By considering both factors as well as properties of the metal ions, some novel host calix[4]arene compounds have been designed for selective separation of $\mathrm{Pb}$ (II). It was reported earlier by our group that tetraacetic acid derivative (4Ac) of calix[4] arene showed a high $\mathrm{Pb}$ (II) selectivity over $\mathrm{Fe}(\mathrm{III}), \mathrm{Cu}(\mathrm{II})$ and $\mathrm{Zn}$ (II) in acidic media due to its suitable coordination site. Moreover, there are four carboxylic acid functional groups, two $\mathrm{Pb}(\mathrm{II})$ ions can be loaded for a single host molecule [15]. Therefore, 4Ac shows a very good selectivity and also extraction ability for $\mathrm{Pb}$ (II). However, the use of calix[4] arene as the extraction reagent has several drawbacks, such as high price and slow kinetics, as it needs $24 \mathrm{~h}$ to reach the equilibrium.

Microreactor is a micro-scale system that employs a reaction process with small amounts of the reactants inside the microchannel having ten to hundred micrometers dimension [16]. The microreactor system has some merits, such as the large surface area per unit volume [17], short diffusion distance for the heterogeneous reaction [18], a reduced amount of reagent [19] and portable analysis [20]. Because of these, the microreactor has been widely applied in protein crystallization [21], organic synthesis [22] and solvent extraction [23]. In our previous work, the precious metal recovery with calix[4]arene derivatives by using the microreactor system was investigated. It shows that high extraction and stripping percentages of $\mathrm{Ag}(\mathrm{I}), \mathrm{Pd}(\mathrm{II})$ and $\mathrm{Pt}(\mathrm{IV})$ were obtained just in few seconds reaction time. The stepwise recovery of these metal ions from the real metal waste was achieved, where calix[4]arene extraction reagent was regenerated after the stripping process [24].

In the present work, the microreactor system was investigated and compared with the batch-wise system as rapid and effective extractive $\mathrm{Pb}(\mathrm{II})$ separation from $\mathrm{Zn}(\mathrm{II}), \mathrm{Cu}(\mathrm{II})$ and $\mathrm{Fe}(\mathrm{III})$ with $4 \mathrm{Ac}$ extraction reagent. The separation process of $\mathrm{Pb}$ (II) from the model mixture containing the $\mathrm{Pb}$ (II), $\mathrm{Zn}(\mathrm{II}), \mathrm{Cu}(\mathrm{II})$ and $\mathrm{Fe}(\mathrm{III})$ was reported. Further, the stripping of $\mathrm{Pb}$ (II) from laden ligand was carried out with nitric acid as stripping reagent, and the regeneration of ligand after the stripping process was confirmed by FTIR study.

\section{- EXPERIMENTAL SECTION}

\section{Materials}

All metal salts in nitrate form, such as $\mathrm{Pb}\left(\mathrm{NO}_{3}\right)_{2}$, $\mathrm{Fe}\left(\mathrm{NO}_{3}\right)_{3}, \mathrm{Cu}\left(\mathrm{NO}_{3}\right)_{2}, \mathrm{Zn}\left(\mathrm{NO}_{3}\right)_{2}$, nitric acid and chloroform are of analytical grade, were purchased from Wako Pure Chemicals (Osaka, Japan). The calix[4]arene derivative, 25,26,27,28-tetrakis(carboxymethoxy)-5,11,17,23-tetrakis (1,1,3,3-tetramethylbutyl)calix[4]arene, was prepared in a similar manner to the procedures previously described by our group [25].

\section{Procedure}

\section{$P b(I I)$ extraction and stripping in individual metal system}

The aqueous phase prepared by mixing $0.1 \mathrm{mM}(\mathrm{M}$ $\left.=\mathrm{mol} \mathrm{dm}^{-3}\right) \mathrm{Pb}(\mathrm{II})$ in $0.1 \mathrm{M}$ HEPES and $0.1 \mathrm{mM} \mathrm{Pb}(\mathrm{II})$ in $0.1 \mathrm{M} \mathrm{HNO}_{3}$ to adjust the $\mathrm{pH}$ solution. The organic phase prepared by dissolving $5.0 \mathrm{mM}$ of $4 \mathrm{Ac}$ in chloroform. Batch-wise extraction carried out by mixing both the phases in equal volumes $\left(3 \mathrm{~cm}^{3}: 3 \mathrm{~cm}^{3}\right)$ at $303 \mathrm{~K}$ with $150 \mathrm{rpm}$ shaking speed. Extraction time was varied $(0.25,0.5,1.0,2.0,4.0,8.0,12.0,16.0,20.0,24.0 \mathrm{~h})$ to find out the optimal time for $\mathrm{Pb}$ (II) extraction. The $\mathrm{Pb}$ (II) concentration before and after extraction was measured by inductively coupled plasma atomic emission spectroscopy (abbreviated as ICP-AES, Shimadzu ICPS8100 , Japan). The extraction percentage $(\% \mathrm{E})$ of $\mathrm{Pb}(\mathrm{II})$ calculated by equation (1),

$\% \mathrm{E}=\frac{[\mathrm{Pb}(\mathrm{II})]_{\mathrm{i}}-[\mathrm{Pb}(\mathrm{II})]_{\mathrm{t}}}{[\mathrm{Pb}(\mathrm{II})]_{\mathrm{i}}} \times 100$

where $[\mathrm{Pb}(\mathrm{II})]_{i}$ and $[\mathrm{Pb}(\mathrm{II})]_{t}$ are the $\mathrm{Pb}(\mathrm{II})$ concentration before and after the extraction process, respectively.

Extraction procedure by using droplet-based microreactor system was carried out in a similar manner to that described previously $[14,24]$ and the experimental setup is shown in Fig. 1. Briefly, the micro-milling process was used to fabricate the glass-glass microreactor device with square microchannels having 200, 200 and 73,000 $\mu \mathrm{m}$ of width, depth, and lengths, respectively. Both phases were injected into the microreactor device through different inlets by using microsyringe pumps (BAS, Model 100, Japan) with an aid 


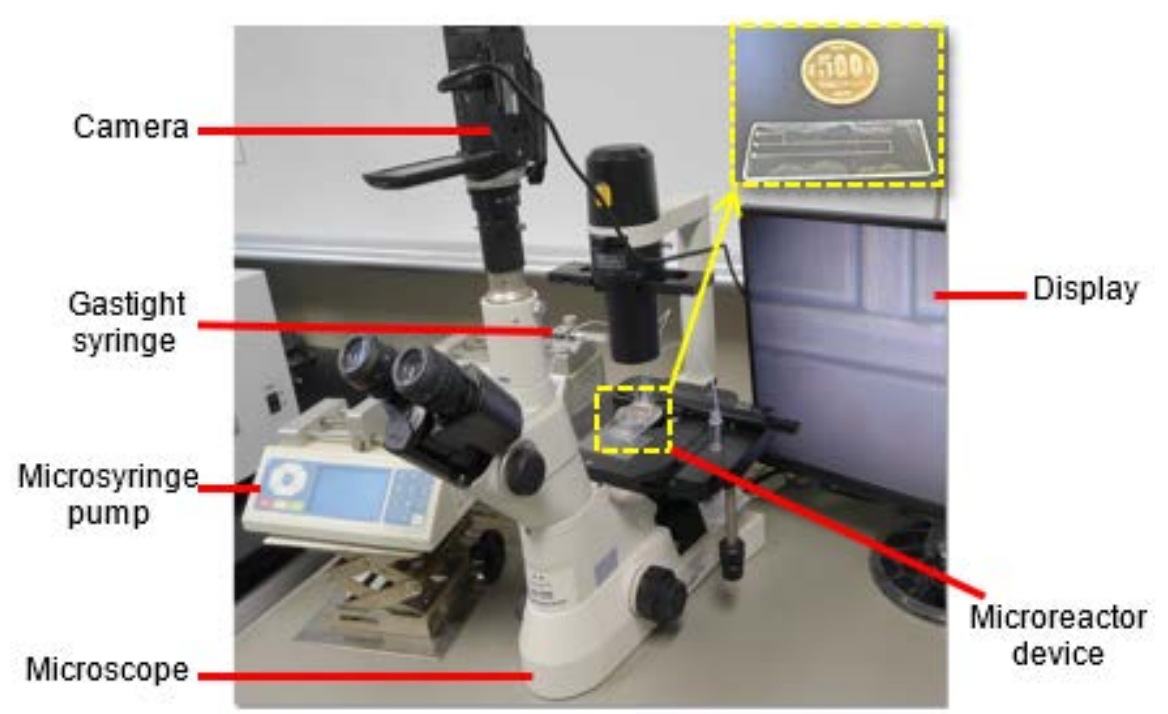

Fig 1. Experimental setup of the droplet-based microreactor system where the microreactor device is shown in the top right corner of the figure

of gastight syringe (Hamilton, Gastight 1001, USA) through PTFE tubes (i.d. $500 \mu \mathrm{m}$ ). The extraction and stripping percentages were investigated by changing the residence time. The volumetric flow rate of each phase was calculated from the ratio of the volume of the microchannel and residence time at room temperature. Both phases were collected in a glass vial and then separated immediately. The $\mathrm{Pb}(\mathrm{II})$ extraction percentage was calculated by the equation (1).

The $\mathrm{Pb}$ (II) stripping process was evaluated from metal-loaded ligand in organic phase by varying nitric acid concentration in 1:1 ratio of volume. The stripping percentage $(\% \mathrm{~S})$ was calculated by the following equation (2),

$\% \mathrm{~S}=\frac{[\mathrm{Pb}(\mathrm{II})]_{\mathrm{aq}}}{[\mathrm{Pb}(\mathrm{II})]_{\mathrm{org}}} \times 100$

where $[\mathrm{Pb}(\mathrm{II})]_{\mathrm{aq}}$ was the $\mathrm{Pb}(\mathrm{II})$ concentration in the aqueous phase after stripping process and $[\mathrm{Pb}(\mathrm{II})]_{\text {org }}$ was the $\mathrm{Pb}(\mathrm{II})$ concentration extracted into the organic phase.

\section{$P b(I I)$ separation from competitive metal system}

A mixture of $\mathrm{Pb}$ (II), $\mathrm{Fe}(\mathrm{III}), \mathrm{Cu}(\mathrm{II})$ and $\mathrm{Zn}$ (II) in 0.1 $\mathrm{mM}$ concentration of each metal ion was prepared in $\mathrm{HEPES} / \mathrm{HNO}_{3}$ buffer media as an aqueous phase, while the $5.0 \mathrm{mM} 4 \mathrm{Ac}$ used as an organic phase. The $\mathrm{Pb}(\mathrm{II})$ separation from other metal ions was carried out in batchwise and microreactor systems as described above. The
$\% \mathrm{E}$ calculated from the ICP-AES measurements and the separation factor for $\mathrm{Pb}(\mathrm{II})$ over $\mathrm{Fe}(\mathrm{III}), \beta_{\mathrm{Pb} / \mathrm{Fe}}$, described by equation (3),

$\beta_{\mathrm{Pb} / \mathrm{Fe}}=\frac{\mathrm{D}_{\mathrm{Pb}(\mathrm{II})}}{\mathrm{D}_{\mathrm{Fe}(\mathrm{III})}}$

where the $\mathrm{D}_{\mathrm{Pb} \text { (II) }}$ and $\mathrm{D}_{\mathrm{Fe}(\mathrm{III})}$ is the distribution factor of $\mathrm{Pb}$ (II) and another metal ion.

\section{Spectroscopic study of the ligand}

The infrared spectra of the 4Ac ligand in the organic phase before and after the $\mathrm{Pb}$ (II) loading and also after stripping process were recorded by using a Fourier transform infrared spectrophotometer (abbreviated as FTIR, Shimadzu IR Affinity 1).

\section{- RESULTS AND DISCUSSION}

\section{$\mathrm{Pb}$ (II) Extraction and Stripping in the Individual Metal System}

The time course dependency for $\mathrm{Pb}$ (II) extraction with $4 \mathrm{Ac}$ was investigated at $\mathrm{pH} 2.00$ in batch and microreactor extraction systems, which are shown in Fig. 2. In a batch system, the extraction rate is slow, it required $24 \mathrm{~h}$ to reach equilibrium. On the other hand, by employing a droplet-based microreactor system, the extraction rate expected to be faster because each droplet works as an individual extraction compartment [24]. Since the microchannel material is made from glass, the 


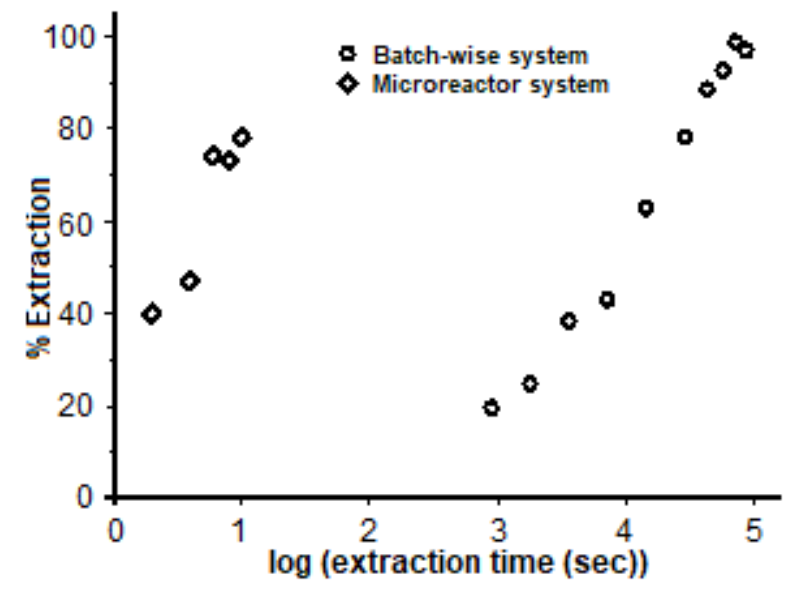

Fig 2. Time course profile of $\mathrm{Pb}(\mathrm{II})$ extraction in batch and microreactor systems

aqueous phase becomes the continuous phase, while the organic phase forms droplets inside the microchannel. The $\mathrm{Pb}$ (II) extraction percentage was $80 \%$ at $6 \mathrm{sec}$ for microreactor system, while to reach the same extraction percentage, the batch system took $8 \mathrm{~h}(28,800 \mathrm{sec})$. In addition, although the temperature for extraction in a microreactor system is lower than the batch system, the microreactor system could enhance the $\mathrm{Pb}$ (II) extraction rate up to $10^{4}$ times faster than batch-wise method due to the characteristics of the high specific surface area, short diffusion distance and rapid vortex mixing in each droplet. It was reported that the extraction rate of $\mathrm{La}$ (III) and $\mathrm{Ce}$ (III) was also enhanced by employing a microreactor system with EHEHPA as an extraction reagent compared with the batch system [26]. However, the enhancement was not so high probably due to using the monodentate EHEHPA ligand. Calix[4]arene as a multidentate ligand that might contribute to the stable complex formation, thus the extraction rate of $\mathrm{Ag}(\mathrm{I})$ ion was drastically enhanced from $72 \mathrm{~h}$ in a batch system to $2 \mathrm{sec}$ in microreactor system [24].

The effect of aqueous phase $\mathrm{pH}$ on extraction percentage of $\mathrm{Pb}(\mathrm{II})$ was also investigated by varying the $\mathrm{pH}$ of the aqueous solution, i.e. 2.00, 2.25 and 2.50, which is shown in Fig. 3. The extraction percentages of $\mathrm{Pb}(\mathrm{II})$ were 73,89 and $100 \%$ at $8 \mathrm{sec}$ residence time for $\mathrm{pH} 2.00$, 2.25 and 2.50 , respectively. The results showed that the $\mathrm{Pb}$ (II) extraction percentage increased with increasing $\mathrm{pH}$

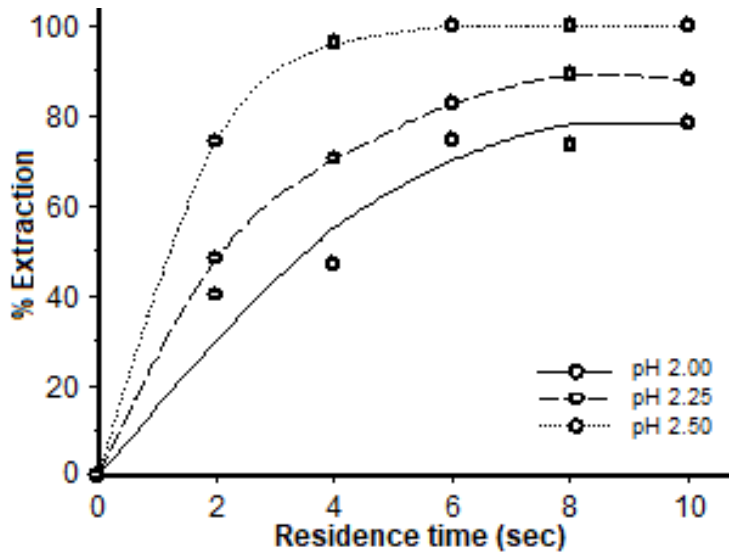

Fig 3. $\mathrm{Pb}(\mathrm{II})$ extraction profile at different $\mathrm{pH}$ of the aqueous phase in the individual metal system by using microreactor system

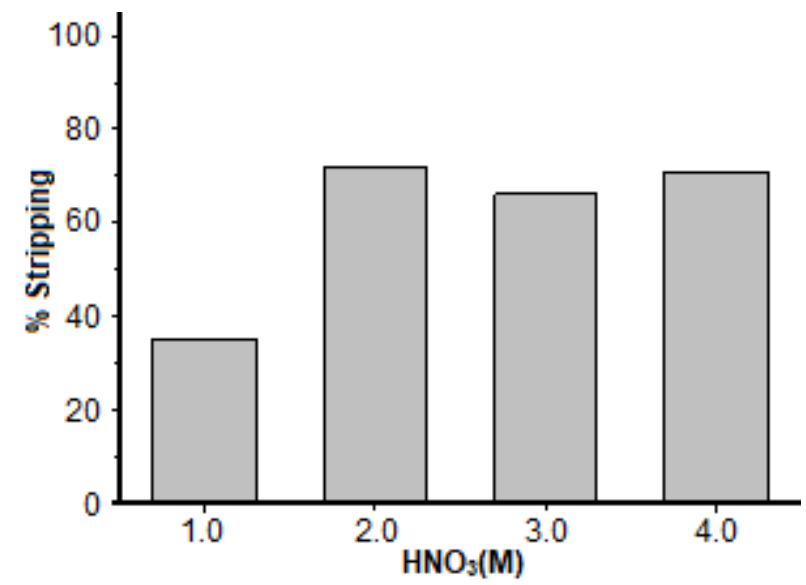

Fig 4. Stripping percentage profile of $\mathrm{Pb}$ (II) with varying concentration of nitric acid as stripping reagent

of the aqueous solution. The carboxylic acid functional groups of the $4 \mathrm{Ac}$ were easy to deprotonate at higher $\mathrm{pH}$ region and the ion exchange reaction took place. The extraction reaction was proposed as in equation (4) [15]. $\mathrm{H}_{4} \mathrm{~L}($ org $)+\mathrm{Pb}^{2+}(\mathrm{aq}) \rightleftarrows\left[\mathrm{Pb}-\mathrm{H}_{2} \mathrm{~L}\right]($ org $)+2 \mathrm{H}^{+}(\mathrm{aq})$

The stripping process of $\mathrm{Pb}(\mathrm{II})$ from the metalladen $4 \mathrm{Ac}$ ligand at $4 \mathrm{sec}$ residence time was evaluated using 1.0, 2.0, 3.0 and $4.0 \mathrm{M} \mathrm{HNO}_{3}$ as stripping reagent by using a microreactor system. The result is shown in Fig 4. The stripping percentage was increased and reached a plateau after using $2.0 \mathrm{M} \mathrm{HNO}_{3}$ as stripping reagent. By increasing residence time, the stripping percentages increased from $51,72,78$ and $92 \%$ for 2,4 , 6 and $8 \mathrm{sec}$ residence time, respectively. It showed that 


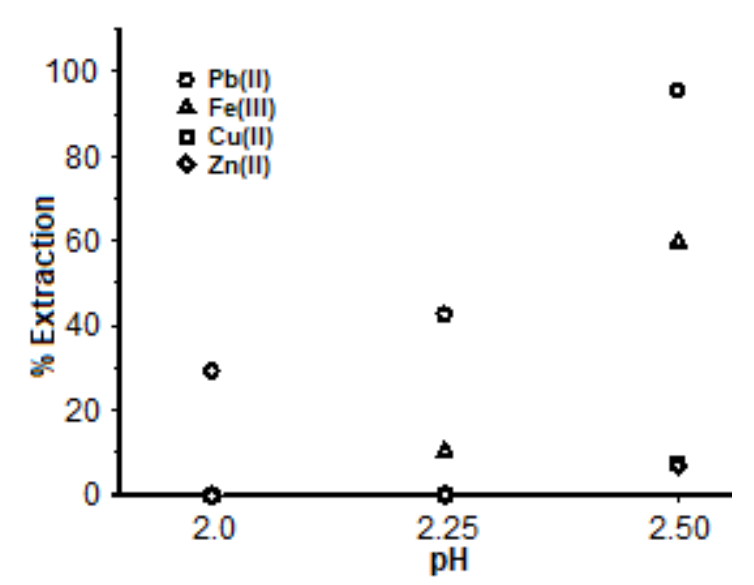

Fig 5. $\mathrm{pH}$ dependency on $\mathrm{Pb}(\mathrm{II})$ separation from the competitive metal system at $4 \mathrm{sec}$ residence time

the stripping rate also enhanced by employing the microreactor extraction method compared with the batch-wise system, although complete stripping was not achieved probably due to short residence time.

\section{$\mathrm{Pb}$ (II) Separation from the Competitive Metal System}

Since 4Ac showed a good extraction ability as well as easy stripping process, the $\mathrm{Pb}$ (II) separation over $\mathrm{Fe}(\mathrm{III})$, $\mathrm{Cu}(\mathrm{II})$ and $\mathrm{Zn}(\mathrm{II})$ metal ions in the competitive metal system was carried out. At first, the extraction process of these metal ions was evaluated by varying the $\mathrm{pH}$ of the aqueous solution at $4 \mathrm{sec}$ residence time as shown in Fig. 5. The increasing $\mathrm{pH}$ of the aqueous solutions also increases the extraction percentages of other metal ions.

Complete separation of $\mathrm{Pb}$ (II) from $\mathrm{Fe}(\mathrm{III}), \mathrm{Cu}$ (II) and $\mathrm{Zn}(\mathrm{II})$ were achieved at $\mathrm{pH} 2.00$ however the $\mathrm{Pb}(\mathrm{II})$ extraction percentage was $29 \%$. On the other hand, $96 \%$ extraction of $\mathrm{Pb}(\mathrm{II})$ was achieved at $\mathrm{pH} 2.50$ but $\mathrm{Fe}(\mathrm{III})$, $\mathrm{Cu}(\mathrm{II})$ and $\mathrm{Zn}$ (II) found to be $60,6.9$ and $7.5 \%$, respectively. Although the $\mathrm{Pb}$ (II) extraction percentage was very high at $\mathrm{pH} 2.50$, the $\mathrm{Pb}$ (II) separation was not achieved well. Application of microreactor system for metal ion separation was also reported by other groups, but complete separation was not achieved even just for two ions model mixture [26-27]. Separation factor for La(III) over Ce(III) with EHEHPA extraction reagent was less than 7.0 and the separation factor was found to decrease by increasing $\mathrm{pH}$ of the aqueous phase and residence time [26]. On the other hand, separation for $\mathrm{Co}(\mathrm{II})$ over $\mathrm{Ni}$ (II)

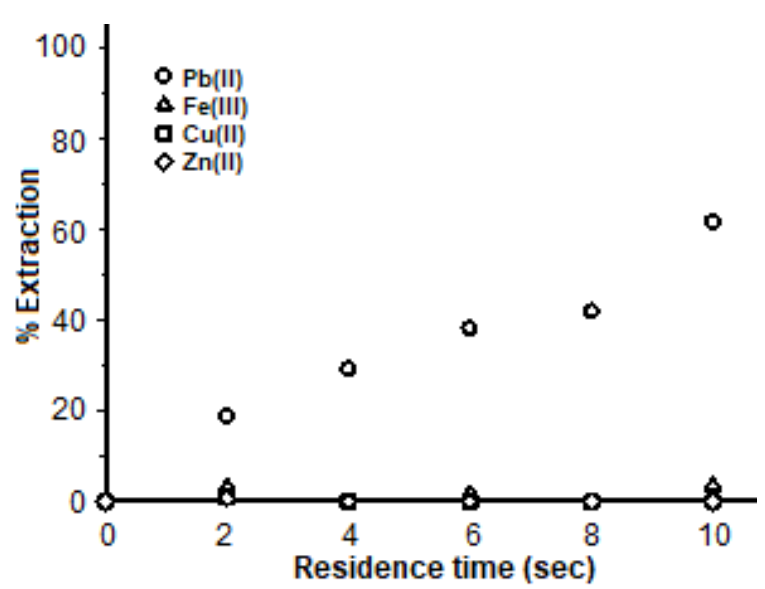

Fig 6. Time course dependency profile of $\mathrm{Pb}(\mathrm{II})$ separation from a competitive metal system at $\mathrm{pH} 2.00$

Table 1. The separation factor of $\mathrm{Pb}(\mathrm{II})$ over $\mathrm{Fe}(\mathrm{III})$ at pH 2.00 to 2.50

\begin{tabular}{lr}
\hline $\mathrm{pH}$ & $\beta_{\mathrm{Pb} / \mathrm{Fe}}$ \\
\hline 2.00 & 973.16 \\
2.25 & 23.27 \\
2.50 & 14.21 \\
\hline
\end{tabular}

with PC88A extraction reagent was less than 32.0 [27]. Poor separation of those ions was mainly caused by the deficient selectivity of the extraction reagent. It was reported earlier by our group [15] that 4Ac extraction reagent has high selectivity for $\mathrm{Pb}$ (II) over $\mathrm{Fe}$ (III), $\mathrm{Cu}$ (II) and $\mathrm{Zn}$ (II) in acidic media. Amazingly, in this study, it was found that by using $4 \mathrm{Ac}$, the separation factor of $\mathrm{Pb}$ (II) over $\mathrm{Fe}$ (III) reached 973.16 at $\mathrm{pH} 2.00$ employing microreactor system. The separation factor of $\mathrm{Pb}$ over $\mathrm{Fe}, \beta_{\mathrm{Pb} / \mathrm{Fe}}$ was decreased by increasing the $\mathrm{pH}$ of the aqueous solution as listed in Table 1 because the extraction reaction of $\mathrm{Fe}(\mathrm{III})$ was different from that of $\mathrm{Pb}$ (II) due to a different charge. While the separation factor of $\mathrm{Pb}$ over $\mathrm{Cu}$ and $\mathrm{Zn}$ were established well at $\mathrm{pH}$ 2.00 to 2.50 . However, in the environment, $\mathrm{Fe}$ (III) was also found together with $\mathrm{Cu}(\mathrm{II})$ and $\mathrm{Zn}$ (II) therefore the time course dependency for $\mathrm{Pb}(\mathrm{II})$ separation over $\mathrm{Fe}(\mathrm{III}), \mathrm{Cu}(\mathrm{II})$ and $\mathrm{Zn}$ (II) were further investigated at pH 2.00. The results are shown in Fig. 6. As mentioned earlier, complete separation of $\mathrm{Pb}(\mathrm{II})$ was achieved and the $\mathrm{Pb}(\mathrm{II})$ extraction percentage was increased with increasing the residence time. It clearly shows that complete separation of $\mathrm{Pb}$ (II) from the competitive metal 


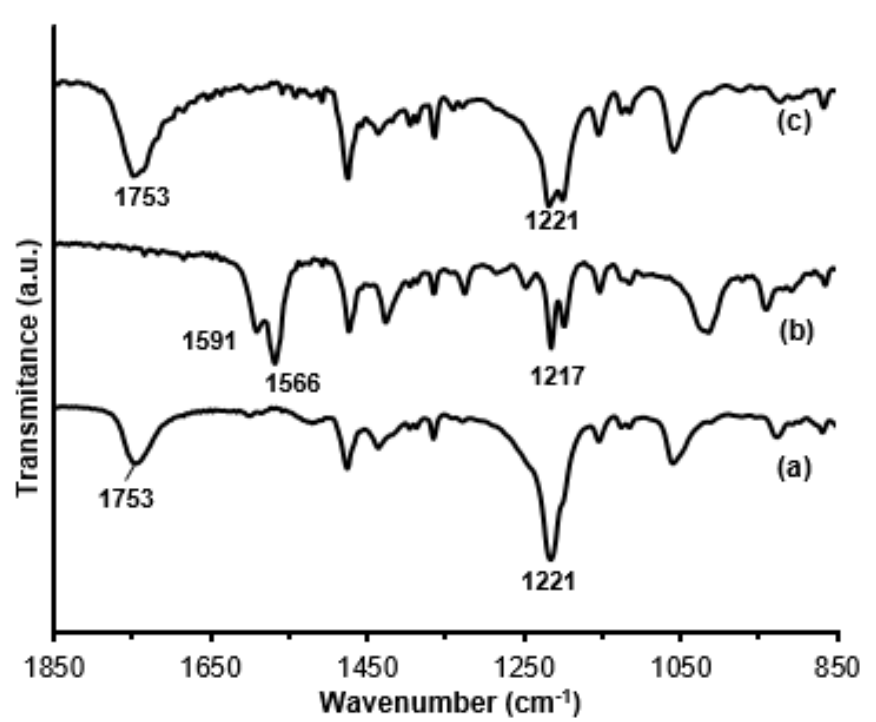

Fig 7. FTIR spectra of 4Ac ligand (a) before and (b) after loading with $\mathrm{Pb}(\mathrm{II})$ ion and (c) after stripping with $2.0 \mathrm{M}$ $\mathrm{HNO}_{3}$ by using microreactor system

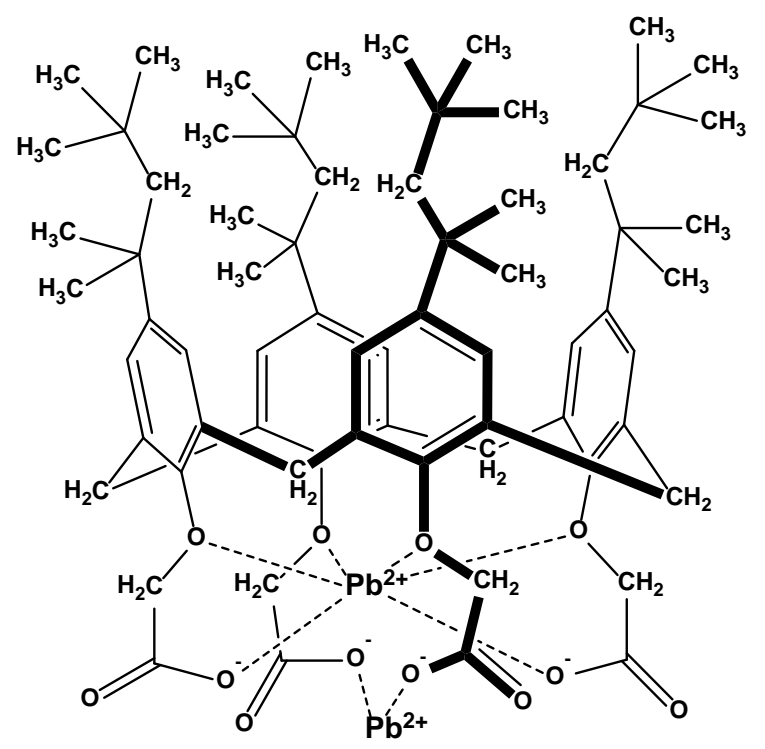

Fig 8. The proposed structure of the $\left[\mathrm{Pb}_{2}-\mathrm{L}\right]$ complex

system was achieved by using microreactor. In our recent study, a success separation of $\mathrm{Pb}$ (II) over $\mathrm{Fe}(\mathrm{III}), \mathrm{Zn}$ (II), $\mathrm{Ni}$ (II), $\mathrm{Co}$ (II), and $\mathrm{Cu}$ (II) ions in $1.0 \mathrm{M} \mathrm{HNO}_{3}$ media was also achieved with an amide derivative of calix[4]arene by using microreactor system [28].

\section{Spectroscopic Study of the Ligand}

To understand the coordination site of $\mathrm{Pb}$ (II) on the 4Ac ligand, the spectroscopic study of the ligand was investigated by FTIR spectra. The FTIR spectra of $4 \mathrm{Ac}$ before and after $\mathrm{Pb}(\mathrm{II})$ loading as well as after stripping with $2.0 \mathrm{M} \mathrm{HNO}_{3}$ are shown in Fig. 7. The $\mathrm{C}=\mathrm{O}$ carbonyl peak was shifted and split from 1753 to 1591 and $1566 \mathrm{~cm}^{-1}$ due to the coordination of two $\mathrm{Pb}$ (II) ions. While C-O phenoxy peak was slightly shifted from 1221 to $1217 \mathrm{~cm}^{-1}$ indicating that the coordination site for $\mathrm{Pb}$ (II) was located between phenoxy oxygen atoms and carbonyl oxygen atoms. It was found that a single molecule of $4 \mathrm{Ac}$ was able to load two $\mathrm{Pb}$ (II) ions through the ion exchange mechanism. The loading reaction was proposed in equation (5) [15].

$$
\mathrm{H}_{4} \mathrm{~L}(\text { org })+2 \mathrm{~Pb}^{2+}(\mathrm{aq}) \rightleftarrows\left[\mathrm{Pb}_{2}-\mathrm{L}\right](\text { org })+4 \mathrm{H}^{+}(\mathrm{aq})
$$

Splitting of $\mathrm{C}=\mathrm{O}$ carbonyl peak was found due to the stepwise loading of two $\mathrm{Pb}$ (II) ions on the single $4 \mathrm{Ac}$ molecule. The $\left[\mathrm{Pb}_{2}-\mathrm{L}\right]$ complex structure was proposed in Fig. 8. The similar spectra with the spectra of a free ligand were obtained after the stripping process. This confirms that the recycling of the extraction reagent was achieved with $2.0 \mathrm{M} \mathrm{HNO}_{3}$ as stripping reagent.

\section{- CONCLUSION}

$\mathrm{Pb}$ (II) extraction and separation over $\mathrm{Fe}(\mathrm{III})$, $\mathrm{Cu}$ (II) and $\mathrm{Zn}$ (II) ions with $4 \mathrm{Ac}$ calix[4] arene derivative was reported by using batch-wise and microreactor extraction methods. Although the batch method required $24 \mathrm{~h}$ to reach the equilibrium for both extraction and stripping process, the microreactor extraction method enhanced the extraction and stripping rate up to $10^{4}$ times faster than batch-wise method. The highest extraction percentage of $\mathrm{Pb}$ (II) was $100 \%$ at $8 \mathrm{sec}$ residence time at $\mathrm{pH} 2.50$, while, the stripping percentage of $\mathrm{Pb}(\mathrm{II})$ was $92 \%$ at 8 sec residence time with $2.0 \mathrm{M} \mathrm{HNO}_{3}$ as stripping reagent by employing microreactor method. Complete separation of $\mathrm{Pb}$ (II) over $\mathrm{Fe}(\mathrm{III}), \mathrm{Cu}(\mathrm{II})$ and $\mathrm{Zn}$ (II) ions in a competitive metal system was achieved at $\mathrm{pH} 2.00$ by a microreactor extraction method in a very short residence time compared with batch method. The FTIR spectra confirm that the extraction reagent was regenerated and repeatedly employed. Therefore, a rapid and efficient separation of $\mathrm{Pb}(\mathrm{II})$ ion, including extraction and stripping with microreactor extraction method has been established. 


\section{- ACKNOWLEDGMENTS}

We thank to Ms. Kazuma Matsuura for her assistance in the microreactor fabrication. This work was partially supported by "Collaborative research expense of partner graduate school between Graduate School of Science and Engineering, Saga University, and AIST Kyushu”.

\section{- REFERENCES}

[1] Pereira, C.J., 1999, Environmental friendly processes, Chem. Eng. Sci., 54 (13-14), 1959-1973.

[2] Anastas, P.T., 2007, Introduction: Green chemistry, Chem. Rev., 107 (6), 2167-2168.

[3] Kurniawan, Y.S., Ramanda, Y., Thomas, K., Hendra, and Wahyuningsih, T.D., 2017, Synthesis of 1,4dioxaspiro[4.4] and 1,4-dioxaspiro[4.5] novel compounds from oleic acid as potential biolubricant, Indones. J. Chem., 17 (2), 301-308.

[4] Wahyuningsih, T.D., and Kurniawan, Y.S., 2017, Green synthesis of some novel dioxolane compounds from Indonesian essential oils as potential biogreases, AIP Conf. Proc., 1823 (1), 020081.

[5] Kurniawan, Y.S., Anwar, M., and Wahyuningsih, T.D., 2017, New lubricant from used cooking oil: Cyclic ketal of ethyl 9,10-dihydroxyoctadecanoate, Mater. Sci. Forum, 901, 135-141.

[6] Gadipelly, C., Pérez-González, A., Yadav, G.D., Ortiz, I., Ibáñez, R., Rathod, V.K., and Marathe, K.V., 2014, Pharmaceutical industry wastewater: Review of the technologies for water treatment and reuse, Ind. Eng. Chem. Res., 53 (29), 11571-11592.

[7] Carolin, C.F., Kumar, P.S., Saravanan, A., Joshiba, G.J., and Naushad, M., 2017, Efficient techniques for the removal of toxic heavy metals from aquatic environment: A review, J. Environ. Chem. Eng., 5 (3), 2782-2799.

[8] Cicero, C.E., Mostile, G., Vasta, R., Rapisarda, V., Signorelli, S.S., Ferrante, M., Zappia, M., and Nicoletti, A., 2017, Metals and neurodegenerative diseases. A systematic review, Environ. Res., 159, 82-94.

[9] Manahan, S., 2017, Environmental Chemistry, $10^{\text {th }}$ ed., CRC Press, New York, 138.
[10] Handayani, D.S., Jumina, Siswanta, D., Mustofa, Ohto, K., and Kawakita, H., 2011, Adsorption of $\mathrm{Pb}(\mathrm{II}), \mathrm{Cd}(\mathrm{II})$ and $\mathrm{Cr}$ (III) from aqueous solution by poly-5-allyl-calix[4]arene tetra carboxylic acid, Indones. J. Chem., 11 (2), 191-195.

[11] Masykur, A., Santosa, S.J., Siswanta, D., and Jumina, 2014, Synthesis of $\mathrm{Pb}$ (II) imprinted carboxymethyl chitosan and the application as sorbent for $\mathrm{Pb}(\mathrm{II})$ ion, Indones. J. Chem., 14 (2), 152-159.

[12] Utomo, S.B., Jumina, Siswanta, D., and Mustofa, 2012, Kinetics and equilibrium model of $\mathrm{Pb}$ (II) and $\mathrm{Cd}(\mathrm{II})$ adsorption onto tetrakis-thiomethyl-C-4methoxyphenylcalix[4] resorcinarene, Indones. J. Chem., 12 (1), 49-56.

[13] Utomo, S.B., Jumina, and Wahyuningsih, T.D., 2009, The adsorption of $\mathrm{Pb}$ (II) and $\mathrm{Cr}$ (III) by polypropyl calix[4]arene polymer, Indones. J. Chem., 9 (3), 437-444.

[14] Ohto, K., 2010, Review of the extraction behavior of metal cations with calixarene derivatives, Solvent Extr. Res. Dev., 17, 1-18.

[15] Ohto, K., Fujimoto, Y., and Inoue, K., 1999, Stepwise extraction of two lead ions with a single molecule of calix[4]arene tetracarboxylic acid, Anal. Chim. Acta, 387 (1), 61-69.

[16] Jensen, K.F., 2017, Flow chemistry-microreaction technology comes of age, AIChE J., 63 (3), 858-869.

[17] Ohto, K., Kim, J.Y., Morisada, S., Maeki, M., Yamashita, K., and Miyazaki, M., 2014, Microreactor extraction system with macrocyclic host compounds for rare metal recovery, Int. J. Soc. Mater. Eng. Resour., 20 (1), 92-96.

[18] Maeki, M., Hatanaka, Y., Yamashita, K., Miyazaki, M., and Ohto, K., 2014, Solvent extraction behavior of metal ions with calix [4] arene derivatives by using a microreactor, Solvent Extr. Res. Dev., 21 (1), 77-82.

[19] Wang, K., and Luo, G., 2017, Microflow extraction: A review of recent development, Chem. Eng. Sci., 169, 18-33.

[20] Busa, L.S.A., Mohammadi, S., Maeki, M., Ishida, A., Tani, H., and Tokeshi, M., 2016, Advances in 
microfluidic paper-based analytical devices for food and water analysis, Micromachines, 7 (5), 86.

[21] Maeki, M., Yamazaki, S., Pawate, A.S., Ishida, A., Tani, H., Yamashita, K., Sugishima. M., Watanabe, M., Tokeshi, M., Kenis, P.J.A., and Miyazaki, M., 2016, A microfluidic-based protein crystallization method in 10 micrometer-sized crystallization space, Cryst EngComm., 18, 7722-7727.

[22] Russo, D., Somma, I.D., Marotta, R., Tomaiuolo, G., Andreozzi, R., Guido, S., and Lapkin, A.A., 2017, Intensification of nitrobenzaldehydes synthesis from benzyl alcohol in a microreactor, Org. Process Rev. Dev., 21 (3), 357-364.

[23] Ciceri, D., Perera, J.M., and Stevens, G.W., 2014, The use of microfluidic devices in solvent extraction, $J$. Chem. Technol. Biotechnol., 89 (6), 771-786.

[24] Sathuluri, R.R., Kurniawan, Y.S., Kim, J.Y., Maeki, M., Iwasaki, W., Morisada, S., Kawakita, H., Miyazaki, M., and Ohto, K., 2018, Droplet-based microreactor system for stepwise recovery of precious metal ions from real metal waste with calix[4]arene derivatives, Sep. Sci. Technol., 53 (8), 1261-1272.

[25] Ohto, K., Yano, M., Inoue, K., Yamamoto, T., Goto, M., Nakashio, F., Shinkai, S., and Nagasaki, T., 1995 , Solvent extraction of trivalent rare earth metal ions with carboxylate derivatives of calix[4]arenes, Anal. Sci., 11 (6), 893-902.

[26] Jiang, F., Yin, S., Srinivasakannan, C., Li, S., and Peng, J., 2018, Separation of lanthanum and cerium from chloride medium in presence of complexing agent along with EHEHPA (P507) in a serpentine microreactor, Chem. Eng. J., 334, 2208-2214.

[27] Zhang, L.H., Ping, J.H., Ju, S.H., Zhang, L.B., Dai, L.Q., and Liu, N.S., 2014, Microfluidic solvent extraction and separation of cobalt and nickel, RSC $A d v ., 4$ (31), 16081-16086.

[28] Kurniawan, Y.S., Sathuluri, R.R., Iwasaki, W., Morisada, S., Kawakita, H., Ohto, K., Miyazaki, M., and Jumina, 2018, Microfluidic reactor for $\mathrm{Pb}(\mathrm{II})$ ion extraction and removal with an amide derivative of calix[4]arene supported by spectroscopic studies, Microchem. J., 142, 377-384. 